\title{
Ikke henrettet allikevel
}

Jeg takker så meget for den hyggelige anmeldelsen av min bok Ondskap i Tidsskriftet nr. 24/2009 (1). Det var svært gode ord, synes jeg, de varmet forfatterens hjerte midt $\mathrm{i}$ den dystre og kalde desember måned. Imidlertid fikk jeg en overraskelse da anmelderen brakte til torgs to henrettede jeg skulle ha oversett! Ifølge Per Holck skal Maria Henriksdatter ha blitt halshugget i 1821 og Karen Jerstad i 1836 for barnedrap. Imidlertid var det heldigvis ikke fullt så blodig.

Maria Henriksdatter Lunden ble dømt for barnefødsel i dølgsmål og utleggelse av falsk barnefar. Dødsdom falt i Høyesterett 14.9. 1821 - hun skulle halshugges. Imidlertid ble hun benådet av Kongen allerede 6. oktober samme år til tukthus «paa Kongens Naade». Hun satt på Christiania tukthus frem til 1825, da hun ble løslatt og tok tjeneste i Ringsaker. Karen Olsdatter Gjerrestad (Jerstad) var en jordmor fra Arendal som i 1835 drepte sitt to og en halv måned gamle barn. Hun fikk dødsdom 15.6. 1835 , men denne ble omgjort til livstid på tukthus 26.8. 1836. Allerede i 1849 vandret hun ut derfra igjen, etter ny kongelig resolusjon av 21.3. 1849 .

Men selv uten disse to solskinnshistoriene er vel resten av boken ille nok, vil jeg tro.

\section{Torgrim Sørnes}

Akershus universitetssykehus

\section{Litteratur}

1. Holck P. Fortidens mordere. Anmeldelse av: Sørnes T. Ondskap. Tidsskr Nor Legeforen 2009 129: $2674-5$.

\section{Tilsvarsrett}

Tidsskriftet praktiserer tilsvarsrett

regler lwww til Vancouver-gruppens

publishing 5 icmje.org/

publishing_5correspond.html).

kommenteres i

kelforfatteres i spalten, får artik-

i samme nummulighet til å svare

tilsvarsrett gjelder Slik automatisk tere av vitensker kun for forfat-

Den gjelder imidlertige artikler.

debatten fortidlertid ikke dersom

Brev til redaketter i spalten

eksempel publiseres dvs. hvis det for

til det første tilsvaret. 